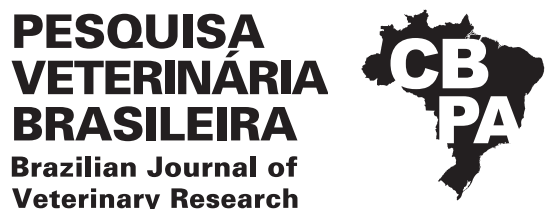

Pesq. Vet. Bras. 41:e06598, 2021

DOI: 10.1590/1678-5150-PVB-6598

Original Article

Small Animal Diseases

ISSN 0100-736X (Print)

ISSN 1678-5150 (Online)

\title{
Accuracy of ARFI elastography in the differentiation of cataract stages in $\operatorname{dog} \mathbf{s}^{1}$
}

\author{
Thais G.M. Abreu², Marjury C. Maronezi², Ricardo A.R. Uscategui ${ }^{3}$, \\ Fabiana L. Rocha², Ivan R.M. Pádua², Gabriela M. Madruga², \\ José L. Laus² and Marcus A.R. Feliciano ${ }^{2,4 *}$ (D)
}

\begin{abstract}
Abreu T.G.M., Maronezi M.C., Uscategui R.A.R., Rocha F.L., Pádua I.R.M., Madruga G.M., Laus J.L. \& Feliciano M.A.R. 2021. Accuracy of ARFI elastography in the differentiation of cataract stages in dogs. Pesquisa Veterinária Brasileira 41:e06598, 2021. Departamento de Clínica e Cirurgia Veterinária, Faculdade de Ciências Agrárias e Veterinárias, Universidade Estadual Paulista "Júlio de Mesquita Filho", Via de acesso Prof. Paulo Donato Castellane s/n, Jaboticabal, São Paulo, SP 14884-900, Brazil. E-mail: marcusfeliciano@yahoo.com.br

Objective was to evaluate the accuracy of elastography in the differentiation between normal and cataract lenses One hundred forty-five eyes of 98 dogs were divided into groups according to cataract stage. Forty-twoeyes were submitted to phacoemulsification. Biometric parameters, echogenicity and echotexture patterns of the anterior, posterior and vitreous chambers, lens and retina-choroid-sclera complexes were evaluated by ocular ultrasound in modes A and B. Deformability, and color (blue color = indicated less rigid structures, color red $=$ more rigid structures) of the lenses were evaluated by the elastogram. The shear wave velocity (SWV; $\mathrm{m} / \mathrm{s}$ ) was calculated in three regions of the lens, both in the cortex and in the nucleus. The SWV of nucleus was statistically different between the normal lenses and with cataracts, and between the stages of cataract $(P<0.001)$. Healthy lenses and incipient cataracts had a more rigid nucleus. Mature cataracts presented lowest nuclear rigidity $(P<0.001)$. On cortical region the SWV was significantly higher $(P<0.01)$ in intumescent and incipient cataracts. SWV less than $2.67 \mathrm{~m} / \mathrm{s}$ indicates cataract with a sensitivity of $72 \%$ and specificity of $94 \%$. Values lower than $2.23 \mathrm{~m} / \mathrm{s}$ suggest mature cataract, with sensitivity of $71 \%$ and specificity of $76 \%$. SWV greater than $2.66 \mathrm{~m} / \mathrm{s}$ are associated with normal lenses or incipient cataract, presenting sensitivity of $94 \%$ and specificity of $84 \%$. Qualitative method allowed differentiation between healthy and affected lenses and the classification of evolutionary stages. There was a correlation between the degree of stiffness of lens in cortical and nuclear regions ( $\mathrm{p}=00165, \mathrm{r}=0.37)$ and between the balanced saline solution quantitative and surgical time $(P<0.01, r=0.73)$. Degree of stiffness of lens did not correlate with parameters of phacoemulsification. Elastographic proved feasible for evaluating the lens of dogs, characterizing the types of cataracts, and demonstrating increased stiffness of the diseased lenses.
\end{abstract}

INDEX TERMS: ARFI, elastography, cataract, dogs, canine, ocular, ultrasound, stiffness.

\footnotetext{
${ }^{1}$ Received on April 12, 2021.

Accepted for publication on May 22, 2021.

${ }^{2}$ Departamento de Clínica e Cirurgia Veterinária, Faculdade de Ciências Agrárias e Veterinárias (FCAV), Universidade Estadual Paulista "Júlio de Mesquita Filho" (Unesp), Via de acesso Prof. Paulo Donato Castellane s/n, Jaboticabal, São Paulo, SP 14884-900, Brazil. *Correspondent author: marcusfeliciano@yahoo.com.br

${ }^{3}$ Universidade Federal dos Vales do Jequitinhonha e Mucuri (UFVJM), Av. Universitária 1000, Unaí, MG 38610-000, Brazil.

${ }^{4}$ Departamento de Clínica de Grandes Animais, Universidade Federal de Santa Maria (UFSM), Av. Roraima 1000, Camobi, Santa Maria, RS 97105900, Brazil.
}

RESUMO.- [Acurácia da elastografia ARFI na diferenciação dos estágios da catarata em cães.] 0 objetivo foi avaliar a precisão da elastografia na diferenciação entre lentes normais e de catarata. Cento e quarenta e cinco olhos de 98 cães foram divididos em grupos de acordo com o estágio de maturação da catarata. Quarenta e dois olhos foram submetidos à facoemulsificação. Parâmetros biométricos, ecogenicidade e padrões de ecotextura das câmaras anterior, posterior e vítrea, lente e complexos retina-coróide-esclera foram avaliados por ultrassonografia ocular nos modos A e B. A 
deformabilidade e a coloração (cor azul = indicou estruturas menos rígidas, cor vermelha = estruturas mais rígidas) das lentes foram avaliadas pelo elastograma. A velocidade da onda de cisalhamento (SWV; $\mathrm{m} / \mathrm{s}$ ) foi calculada em três regiões da lente, tanto no córtex quanto no núcleo. A SWV do núcleo foi estatisticamente diferente entre as lentes normais e com catarata e entre os estágios da catarata $(P<0,001)$. Lentes saudáveis e cataratas incipientes tinham um núcleo mais rígido. Cataratas maduras apresentaram menor rigidez nuclear $(P<0,001)$. Na região cortical, a SWV foi significativamente maior $(P<0,01)$ nas cataratas intumescentes e incipientes. Uma SWV menor que $2,67 \mathrm{~m} / \mathrm{s}$ indica catarata com sensibilidade de $72 \%$ e especificidade de $94 \%$. Valores inferiores a 2,23m/s sugerem catarata madura, com sensibilidade de $71 \%$ e especificidade de $76 \%$. Uma SWV superior a $2,66 \mathrm{~m} / \mathrm{s}$ está associada à catarata normal ou incipiente, apresentando sensibilidade de 94\% e especificidade de $84 \%$. 0 método qualitativo permitiu a diferenciação entre lentes normais de olhos saudáveis e afetadas e a classificação dos estágios evolutivos. A elastografia se mostrara uma ferramenta viável para avaliar as lentes de cães, caracterizando os tipos de catarata e demonstrando maior rigidez das lentes doentes.

TERMOS DE INDEXAÇÃO: Elastografia, ARFI, catarata, cães, caninos, ocular, ultrassom, rigidez.

\section{INTRODUCTION}

Cataracts are considered as the greatest cause of blindness in both humans and dogs (Temporini \& Kara 2004, Ofri 2013). Since, higher life expectancy is one of its causes, studies on the stages of cataract, lens characteristics in cataract, and especially about surgical treatment are required to determine the prognosis of the functional vision (Adkins \& Hendrix 2005, Pigatto et al. 2007, Safatle et al. 2010).

Elastography is based on the principle of elasticity (Young's modulus), in which the concerned tissue is subjected to a force. The degree of deformation depends on the tissue's stiffness. In general, more rigid tissues suffer less deformity and after cessation of the applied force, the tissue returns to its original shape. This technique is performed in real-time, non-invasively, and more often does not require sedatives or anesthetics (Carvalho et al. 2015, Abreu et al. 2018). Currently there is no study that uses the elastography for the diagnosis of cataracts in animals or humans.

The developmental stages of cataract are identified by slit lamp biomicroscopic, after administration of mydriatic eyedrops, and a subjective evaluation of lenticular opacity (Mould 2002). Although it is possible to infer the degree of lens opacity based on its echogenicity and echotexture by $\mathrm{A}$ and B-mode ultrasonography, it does not support the measurement of rigidity (Martins et al. 2010). Therefore, the methods used in the classification of the stages of cataract are subjective and limited, and can affect the choice of the most appropriate therapy, as well as establishing prognostic value of surgery.

Most methods proposed for the investigation of lens stiffness are performed in vitro and did not include canine subjects (Antunes et al. 2006, Czygan \& Hartung 1997). The methods include the automated hydrostatic guillotine, which cuts the lens with water pressure measuring the force required for its separation; linear compression plates; penetrating inventor; and high-frequency ultrasonic needle transducer (Assia et al. 1997, Czygan \& Hartung 1997, Smith et al. 2002, Huang et al. 2009). Studies have also reported association between images obtained from an ocular ultrasound with the results of guillotine test to determine the relationship between the density of the tissue and its acoustic characteristics (Tabandeh et al. 2000).

The success of phacoemulsification surgery depends on the physical properties of the lens, and given the lack of an in vivo method to evaluate hardness of cataractous lenses. The aim of this study was to investigate acoustic radiation force impulse (ARFI) elastography in differentiating between cataractous and normal lenses; and to classify the stages of cataract in dogs. We hypothesized that these findings can be useful not just as a diagnostic measure, but also as a reliable method to establish the correct prognosis for patients undergoing phacoemulsification surgery.

\section{MATERIALS AND METHODS}

This study was approved by the institution's ethics committee under the protocol number $005572 / 17$. The owners of the dogs selected for this study authorized the participation of their dogs by signing a free and informed consent term. All dogs included in the study were from the "Serviço de Oftalmologia Veterinária" of the "Hospital Veterinário", "Departamento de Clínica e Cirurgia Veterinária" (FCAV), "Universidade Estadual Paulista 'Júlio de Mesquita Filho'” (Unesp, Jaboticabal).

The canine subjects were classified into six groups according to the developmental stage of cataract as healthy, incipient cataract, immature cataract, mature cataract, intumescent cataract, and hypermature cataract. The study of the different developmental stages of cataract such as incipient, mature, hypermature, and intumescent, is justified considering that this classification is commonly used in studies involving lenses (Ofri 2013). Considering a statistical significance level of 5\%, a minimum sample size of 20 eyes was established for each of the developmental stage and healthy eyes group.

Physical, laboratorial (complete blood count, creatinine, and alanine aminotransferase - ALT), and ophthalmic examinations were performed for all the subjects in the study. Ocular examination included direct and consensual pupillary reflexes, menace response, Schirmer's lacrimal test, slit-lamp biomicroscopic, applanation tonometry, binocular indirect ophthalmoscopy, fluorescein and tearfilm rupture test, and ocular ultrasonography on A and B-mode. Dogs of the "healthy" group, presented with no abnormalities on physical, laboratorial, and ophthalmic examinations. The dogs that presented with cataract were classified according to the development stage based on evaluation of the lenses with menace response, slit-lamp, and ultrasonography (A and B-mode).

Canine subjects classified under "incipient cataract" presented with positive menace response, corneal opacity $>15 \%$ of the lens at slit-lamp, low peak formation, and a small region of hyperechogenicity on ocular ultrasonography. The "immature cataract" group had decreased menace response; lenticular opacity $<15 \%$, especially in the central region; moderate peak formation; and incomplete hyperechogenicity of the lens on ocular ultrasound. In the "mature cataract" group, patients showed negative menace response, complete lenticular opacity, peak formation, and complete hyperechogenicity of the lens on ocular ultrasound (Ofri 2013).

Eyes of the canine subjects classified as "intumescent cataracts" presented with negative menace response, complete opacity of the lens, peak formation, and hyperechogenicity associated with hypoechogenicity observed throughout the lens extension on 
evaluation of the ultrasonography, lenticular thickness $>7 \mathrm{~mm}$, and anterior chamber decrease. The canine patients of the "hypermature cataract" group showed negative menace response, complete opacity and capsule roughness prior to slit-lamp evaluation, peak formation, hyperechogenicity throughout the lens on ultrasonographic evaluation, and presence of irregularities in the anterior capsule (Ofri 2013).

To perform ocular ultrasonography and elastography, the corneas were desensitized with proxymetacaine hydrochloride $(0.5 \%)$ eyedrop (Anestalcon, Alcon, SP, Brazil). Sterile acoustic gel (Supra Gel, Adlin Plásticos LTDA, Jaraguá do Sul/SC, Brazil) was used as contact medium for the transcorneal method. Chemical restraint was not needed.

The A and B-mode ocular ultrasounds were performed with Ultrascan A/B equipment (Alcon Laboratories, INC-USA) using a $20 \mathrm{MHz}$ probe in axial position by a trained examiner. Biometric parameters (diameter, length, and thickness measured in $\mathrm{mm}$ ), echogenicity, and echotexture patterns of the anterior, posterior, and vitreous chambers, lens, and retinal-choroid-sclera complexes were evaluated.

The device employed for elastography was the Acuson S2000/ Siemens (Siemens Medical Solution, USA, INC-USA) using the ARFI method (Virtual Touch software) with a $9.0 \mathrm{MHz}$ transducer by an experienced sonographer. For the qualitative study, deformability of the lenses was assessed (deformable or non-deformable) from the different colors of the elastogram. Blue color indicated fewer rigid structures than those of green color (intermediate rigidity), and the red color showed the most rigid structures. The quality of the images was tested using a display device in which homogeneous and greenish images indicated high quality, while heterogeneous and yellowish images indicated low quality. After the qualitative analysis, three regions of interest, covering the entire length of the lens both in the cortex and in the nucleus were defined by positioning the caliper over these areas. Using this methodology, the software automatically calculates the shear wave velocity (SWV) in $\mathrm{m} / \mathrm{s}$ of each region and the mean of which was calculated for statistical analysis (Abreu et al. 2018).

Statistical analysis was performed using R software (RTM Foundation for statistical computing, Austria). SWVs of the cortex and lens nucleus were compared between the cataract stages of the groups using the Kruskal Wallis test and the Dunns post-test, and the results were presented as median \pm interquartile range (IQR). Parameters with significant differences $(P<0.05)$ between cataract stages were, subsequently, submitted to a discriminative power analysis through receiver operating characteristic (ROC) curves and cutoff value, sensitivity, specificity, and area under the curve (AUC) were calculated using a logistic regression model. Significance level was set at $5 \%(P<0.05)$ for all tests.

\section{RESULTS}

Twenty eyes with healthy lenses were studied. In the cataract groups, the following numbers were acquired: 20 incipient, 20 intumescent, 20 immature, 45 mature, and 20 hypermature. The study included 145 eyes of 98 dogs of different breeds, adults from two to 12 years (mean age $5.85 \pm 2.88$ years), males (23.81\%), and females (76.19\%).

In the elastogram, normal lenses presented with poor image quality and no homogeneity in color on evaluation. In general, cataractous lenses showed high image quality and homogeneity in the color patterns, especially for regions with lenticular opacity (Fig.1-10). Lenses with incipient cataracts were blue for the affected regions and showed poor image quality for the non-affected regions. Intumescent cataracts presented with blue cortex and some small regions of green. However, on examination, the nucleus showed as having poor image quality. In immature cataracts, there was a predominance of blue and some areas of green, although high image quality was observed only for regions of opacity. Mature cataracts had high image quality throughout the lens with predominant blue tone and some nuclear regions as green. In case of hypermature cataracts, the lenses were presented as high image quality showing a predominance of blue with some greenish and reddish tones.

Table 1 shows the minimum, maximum, median, IQRs and Confidence intervals (CI-95\%) of cortical and nuclear SWVs of healthy lenses and the different stages of cataract. Whereas, in the healthy lenses, it was possible to obtain values related
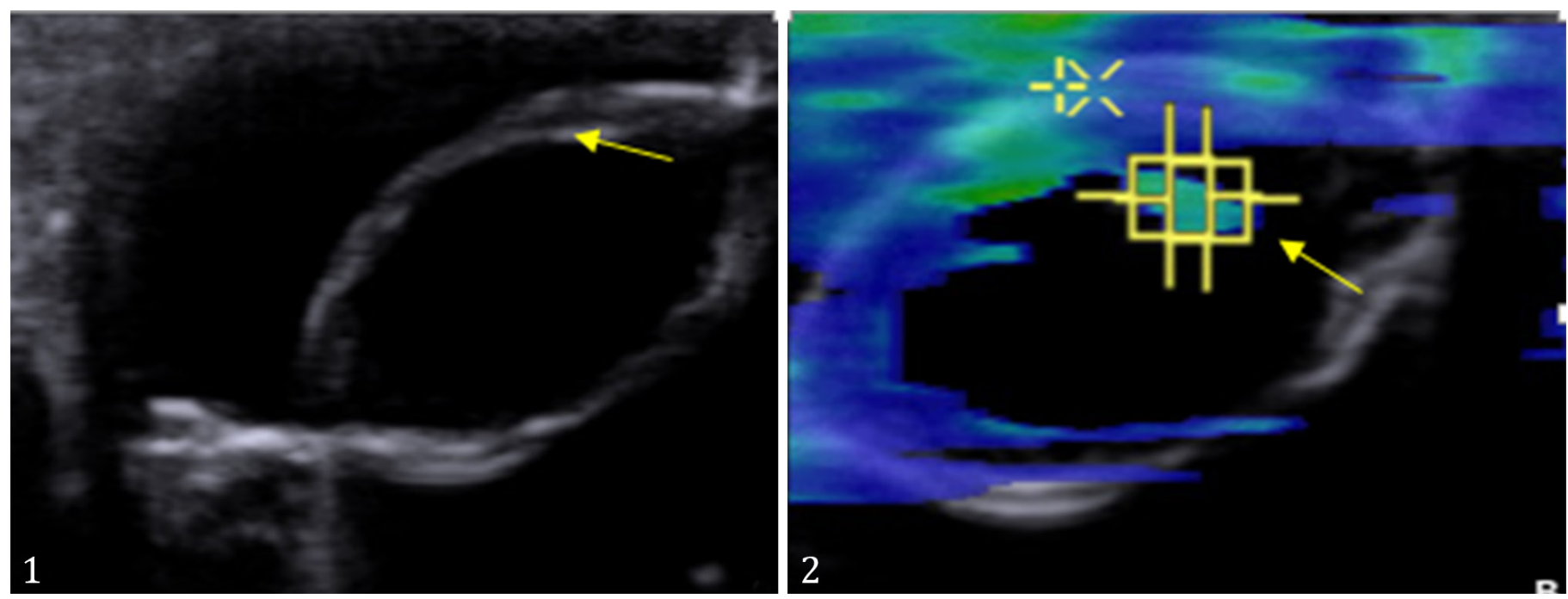

Fig.1-2. (1) B-mode and (2) elastogram of a dogs with cataract showing different colours of the lens. Dog with incipient cataract: (1) hyperechogenicity of anterior capsule (yellow arrow) coincident with ophthalmic opacity and (2) blue colour (yellow arrow) (soft) in the region of opacity due to cataract. 

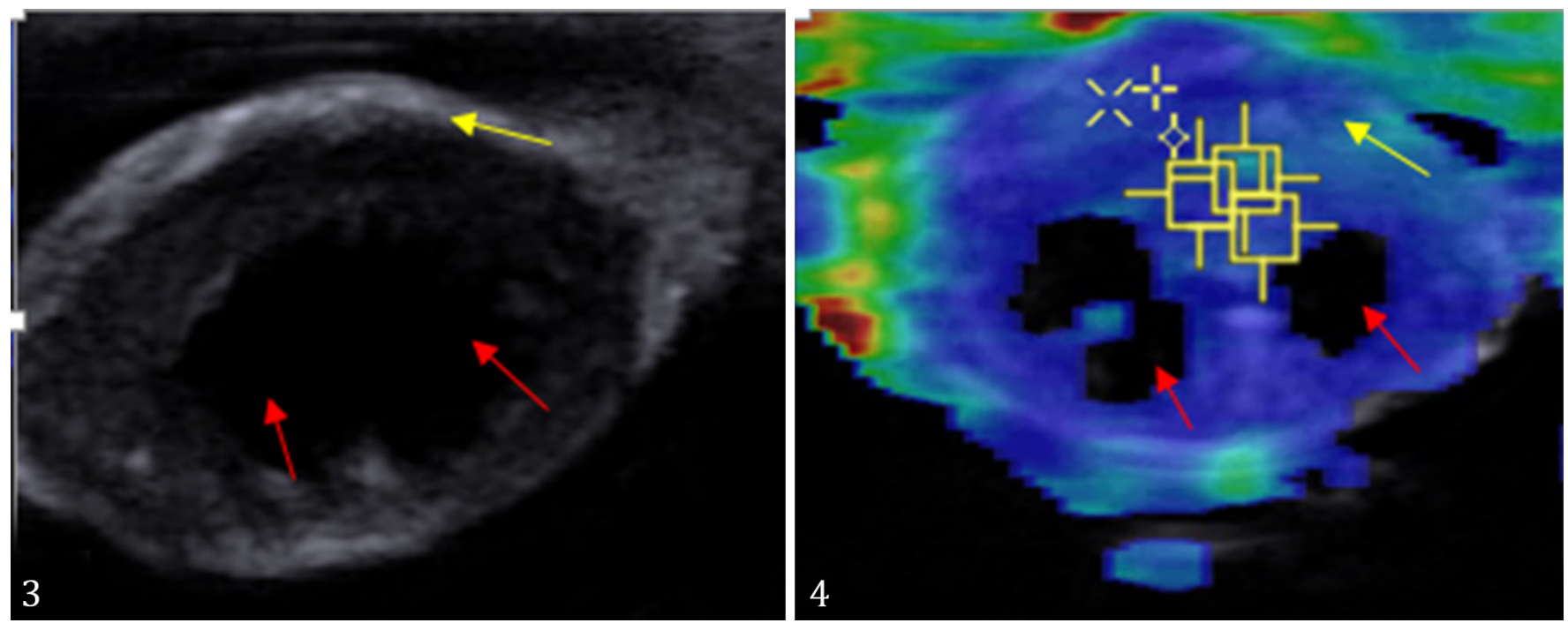

Fig.3-4. (3) B-mode and (4) elastogram of a dogs with cataract showing different colours of the lens. Dog with intumescent cataract: (3) areas of hyperechogenicity (yellow arrow) and anechogenicity (red arrows) (regions with aqueous content) and (4) blue colour (soft) in the region of opacity caused by the cataract (yellow arrow) and absence of colour due to the aqueous content (red arrows) characteristic of this stage.

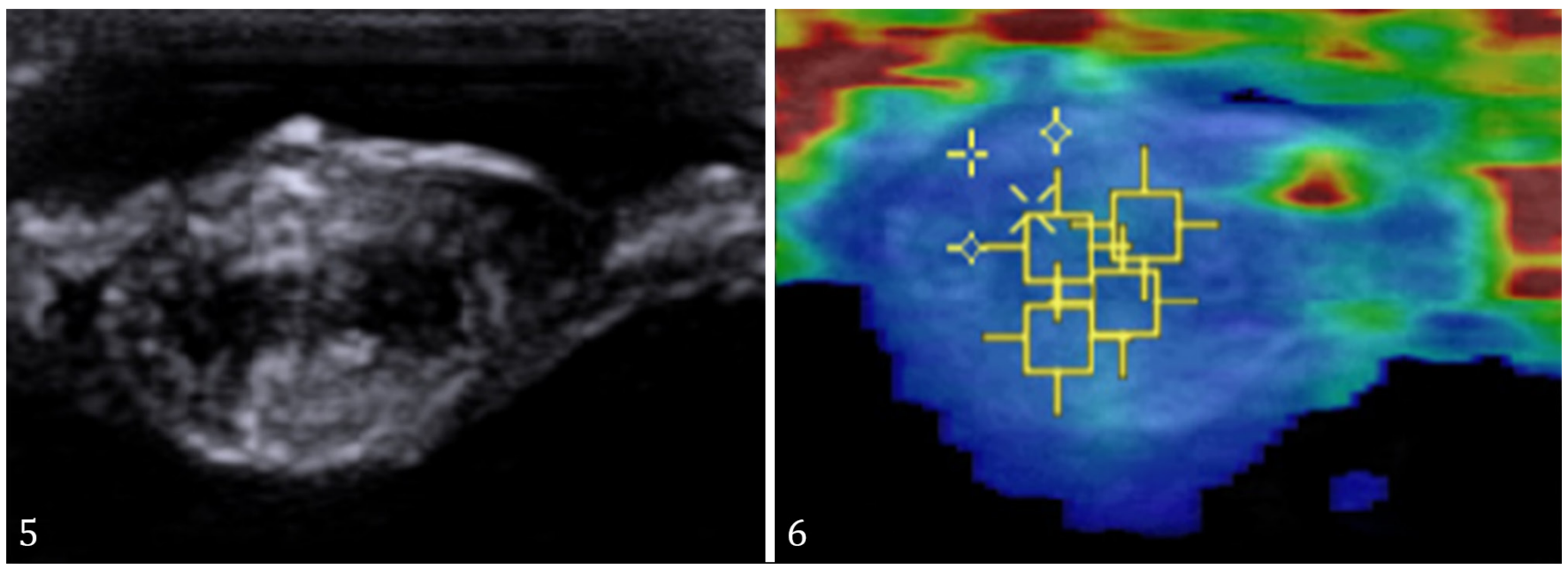

Fig.5-6. (5) B-mode and (6) elastogram of a dogs with cataract showing different colours of the lens. Dog with immature cataract: (5) hyperechogenicity in almost the entire lenticular surface and (6) blue colour (soft) throughout the lens extension.
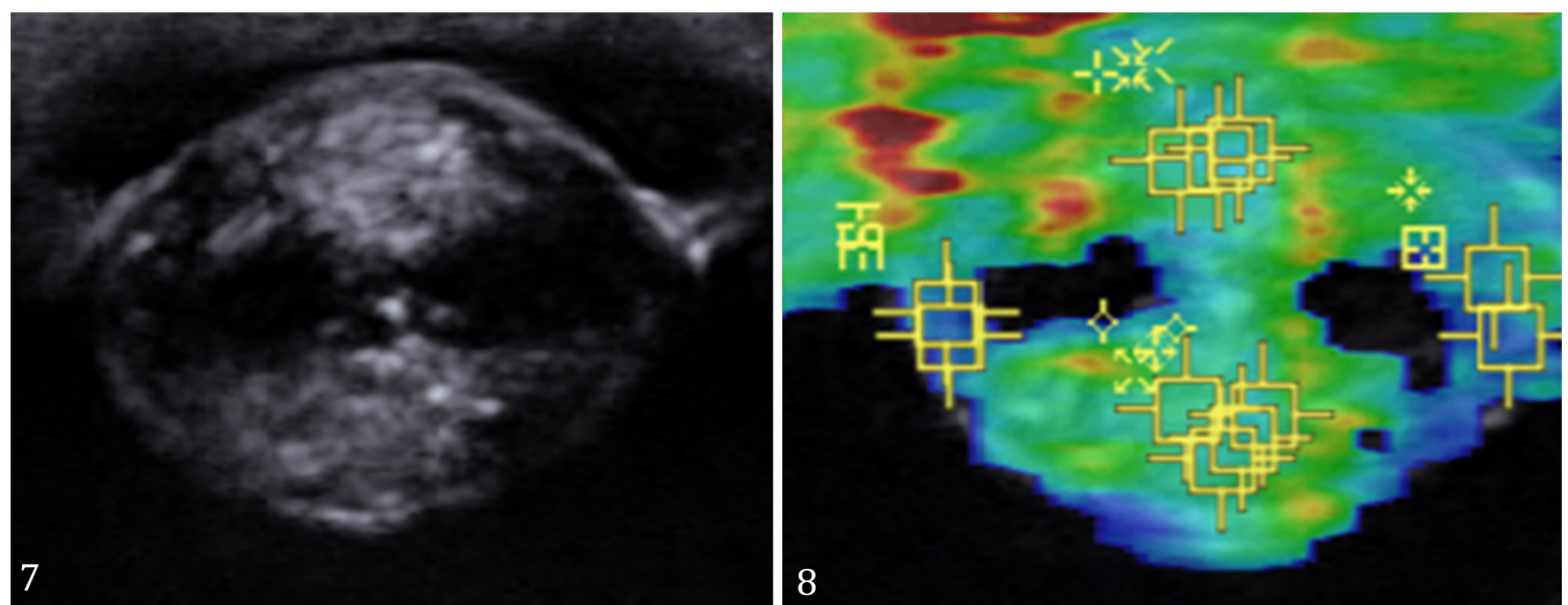

Fig.7-8. (7) B-mode and (8) elastogram of a dogs with cataract showing different colours of the lens. Dog with mature cataract:

(7) hyperechogenicity throughout the lens and (8) green colour throughout the lens. 

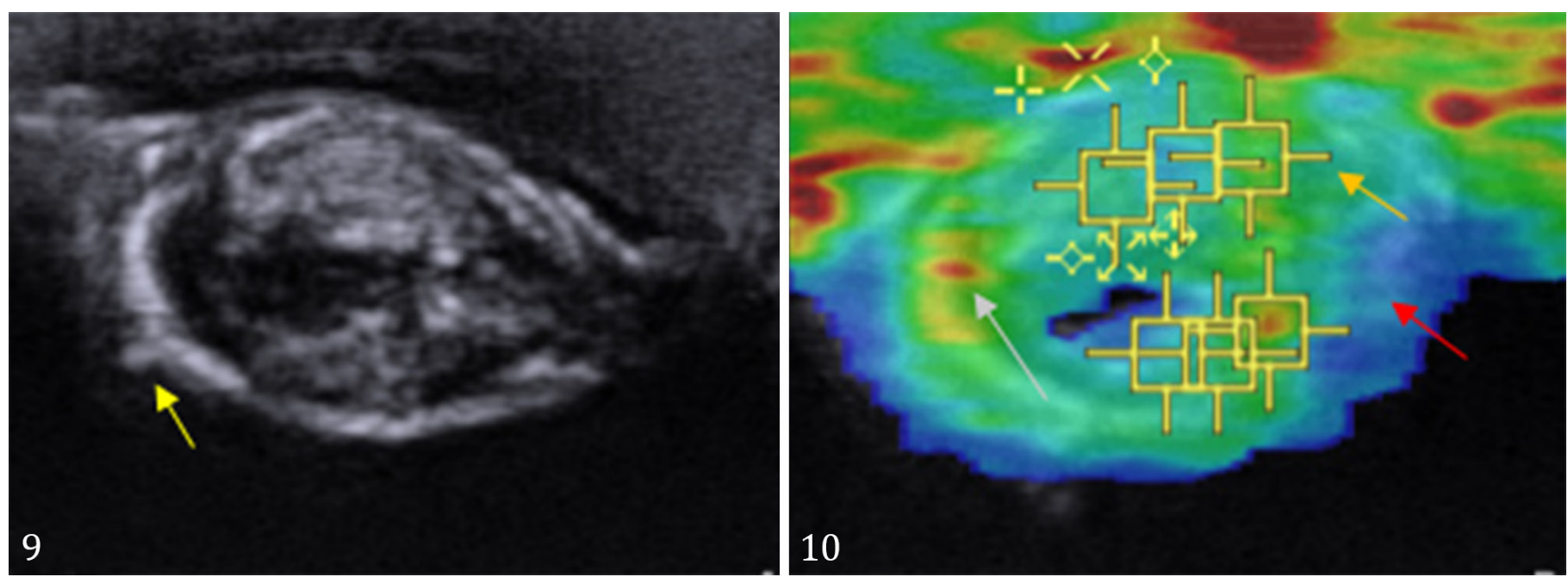

Fig.9-10. (9) B-mode and (10) elastogram of a dogs with cataract showing different colours of the lens. Dog with hypermature cataract: (9) hyperechogenicity of the entire lens and anterior capsule irregularity (yellow arrow) and (10) blue colour (red arrow) of the entire lens, some greenish regions (orange arrow) (intermediate stiffness), and the others reddish (gray arrow) (high stiffness).

Table 1. Minimum, maximum, median, and interquartile range (IQR) of the cortical and nuclear shear velocities (m/s) of healthy lenses and of different stages of cataract

\begin{tabular}{|c|c|c|c|c|c|c|}
\hline Variable & Stage & Minimum & Median & Maximun & IQR & Mean - CI \\
\hline \multirow[t]{5}{*}{ SWV - Nucleous (m/s) } & Hipermature & 1.020 & $2.480^{\mathrm{b}}$ & 2.990 & 0.893 & $2.1-2.8$ \\
\hline & Imature & 1.930 & $2.360^{\mathrm{b}}$ & 3.00 & 0.387 & $2.3-2.6$ \\
\hline & Intumescent & 1.100 & $2.160^{\mathrm{b}}$ & 3.680 & 0.542 & $2.1-2.6$ \\
\hline & Mature & 1.090 & $2.050^{c}$ & 3.460 & 0.780 & $1.8-2.2$ \\
\hline & \multicolumn{6}{|c|}{$P<0.001$} \\
\hline \multirow[t]{3}{*}{ SWV - Cortex (m/s) } & Hipermature & 1.260 & $2.370^{\mathrm{b}}$ & 3.140 & 0.720 & $1.9-2.6$ \\
\hline & Imature & 1.500 & $2.205^{\mathrm{b}}$ & 3.390 & 0.435 & $2.1-2.5$ \\
\hline & Incipient & 1.750 & $2.505^{\mathrm{a}}$ & 2.950 & 0.302 & $2.4-2.6$ \\
\hline
\end{tabular}

$\mathrm{m} / \mathrm{s}=$ Meters per second, $\mathrm{CI}=$ confidence interval, $\mathrm{N} / \mathrm{A}=$ measure not available; ${ }^{\mathrm{a}, \mathrm{b}, \mathrm{c}}$ Median stages of cataract with different superscript letters are significantly different $(P<0.01)$.

to the nucleus only, since the cortical region had an SWV of $\mathrm{XX} \mathrm{m} / \mathrm{s}$, that is assumed to be indicative of a value below or above the limit and, therefore, was not measurable by the equipment. On the other hand, in the incipient cataracts, it was possible to measure the SWVs of the cortex only due to the opacity and, therefore, displayed as good image quality on examination.

The difference in the SWVs of the nucleus between the different stages of cataract, and that between the healthy lenses and the affected ones was statistically significant $(P<0.001$; Fig.11-13). Healthy lenses and those with incipient cataracts had a more rigid nucleus $(P<0.001)$ than those with hypermature, immature, and intumescent cataracts. Mature cataracts presented with lowest nuclear rigidity when compared to the others $(P<0.001)$. The cortical SWV was significantly higher $(P<0.001)$ for the intumescent and incipient cataracts than for the other stages (Fig.11-13).

Based on an elastography evaluation, an SWV of the lens nucleus $<2.67 \mathrm{~m} / \mathrm{s}$ is indicative of cataract. The capacity of elastography to predict a cataract stage showed a sensitivity of $72 \%$, specificity of $94 \%$, and AUC of $82 \%$ (Fig.11-13). Additionally, a value $<2.23 \mathrm{~m} / \mathrm{s}$ indicates a mature cataract, with sensitivity of $71 \%$, specificity of $76 \%$, and AUC of $76 \%$. Furthermore, an SWV $>2.66 \mathrm{~m} / \mathrm{s}$ is suggestive of a lens that is healthy or has incipient cataract, with a sensitivity of $94 \%$, specificity of $84 \%$, and AUC of $89 \%$. 

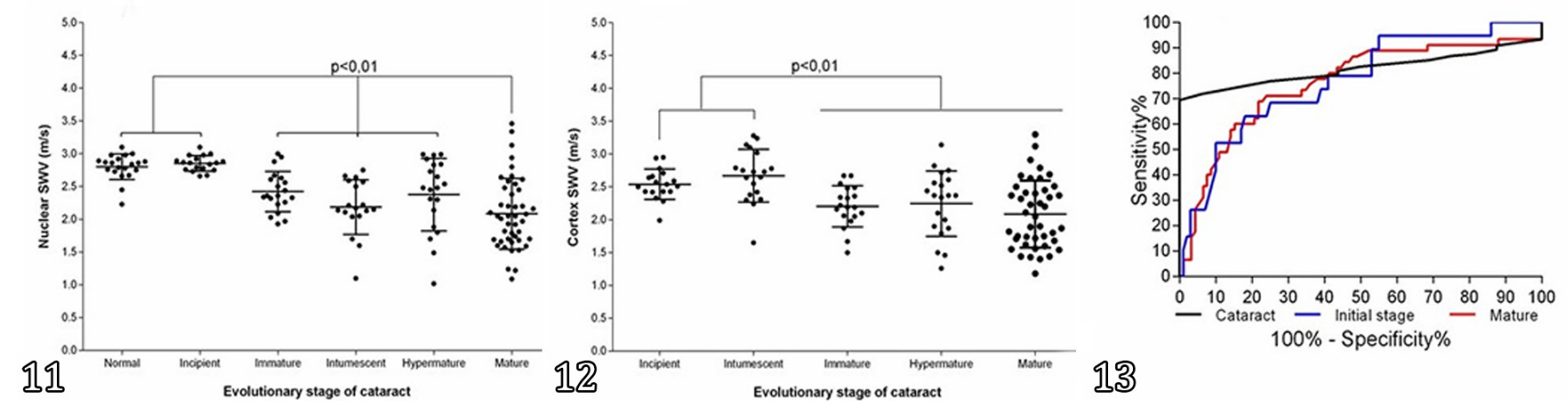

Fig.11-13. (11) Variation of the shear velocity of the nucleus through ARFI elastography in healthy lenses and at different stages of cataract $(P<0.001)$. (12) Shear velocity of the cortex through ARFI elastography of intumescent and incipient cataracts, significantly higher $(P<0.01)$ than the other stages of cataract. (13) Sensitivity and specificity of shear velocity through ARFI elastography of lenses with cataract at different stages of development.

\section{DISCUSSION}

The structure of the intraocular lens will changes depending on the evolutionary degree of the cataracts and this changes that determine the degree of opacity of the lens. Quantitative and qualitative differences in stiffness observed between healthy lenses and different developmental stages of cataract, may be explained by the composition and organization of the lenses, emphasizing the importance of elastography in such cases. Healthy lenses are basically composed of aqueous content and $33 \%$ of protein fibers organized in the lamellae (Kuszak et al. 2004a, 2004b). During the development of cataract, there is a disorganization of the lamellar arrangement (Galego et al. 2012) and dehydration of the lens, leading to opacity, which results in variable visual deficiency, according to the stages of development of the condition (Czygan \& Hartung 1997, Kleiner 2007, Gelatt \& Wilkie 2011, Galego et al. 2012).

Tissues affected by different diseases present with changes in their components and/or molecular organizations, that directly interferes with its biomechanics (Shah et al. 2007), and consequently, with the rigidity of the tissue, as was observed in the present study (Paszek et al. 2005).

The distinction in stiffness observed between the nucleus and the cortical areas may be explained by the anatomical and physiological characteristics of the lens. The epithelial cells below the anterior capsule are responsible for the production of lenticular fibers during its life, forming the cortex and the nucleus (Dick et al. 2008). Fibers from the nuclear region are called primary fibers and are older than the secondary fibbers present in the cortex (Kuszak et al. 2004a, Dick et al. 2008). The authors suggest that such structural variations within the lens may interfere with the results of an elastography, explaining the differences of the nuclear region (primary and old fibers) than the cortex region (secondary and new fibers).

Elastogram revealed variations in rigidity for different stages of cataract, which corroborates with previous studies in humans using the guillotine system (Assia et al. 1997), linear compression plates (Smith et al. 2002), penetrating indentor (Czygan \& Hartung 1997) and ultrasonography (Tabandeh et al. 2000, Huang et al. 2007).

According to a colored elastogram, it is to be noted that structures with large aqueous content are presented as poor quality on examination. Considering that incipient cataracts have up to 15\% opacity of the lens (Ofri 2013), the images with blue shades occurred only in the small region affected by opacity, whereas, the healthy areas that maintained enough aqueous content showed as poor quality on examination.

Intumescent cataracts are more frequent in diabetic patients and are characterized by higher aqueous content due to the osmotic gradient facilitated by sorbitol (Galego et al. 2012); that explains the mixed patterns of low stiffness (blue color) and poor image quality (aqueous content) observed for this stage. In this study all patients with intumescent cataracts were diabetic. In immature cataracts, opacity occurs partially (Gelatt \& Wilkie 2011). In the elastogram it was noted that the lenses presented with no color in regions with aqueous content and regions of green indicating an intermediate level of stiffness. On the other hand, in mature cataracts the opacity is complete and presents with visual deficit (Rodrigues et al. 2010), corroborating with the qualitative evaluation in which the entire lens was colored, representing both low and intermediate degrees of rigidity. The same was observed for the hypermature stage; however, due to the higher composition of compact fibers and loss of aqueous content (Gelatt \& Wilkie 2011), some areas presented with high stiffness (red).

Studies on lenticular stiffness in humans are commonly performed ex vivo (Assia et al. 1997, Czygan \& Hartung 1997, Smith et al. 2002) and in vitro (Huang et al. 2007); however, fewer are performed in vivo (Tabandeh et al. 2000). Compared to these studies which showed that the more advanced cataract showed greater rigidity of the lens due to increased protein concentration and disorganization of the lenticular fibers (Kurapkienė et al. 2005), in our study, it was observed that normal and incipient cataracts presented higher stiffness on the nuclear region (higher SWVs) than the other stages. This finding is justified from the poor image quality obtained on examination of the healthy lenses and incipient cataracts. The authors of this study have suggested that the equipment is more reliable in the evaluation of advanced cataract (mature and hypermature) due to lower aqueous content, thereby justifying the difference in our results and in vitro studies.

\section{CONCLUSIONS}

Qualitative method was useful in the study of stiffness in each region of the lens and could be useful as a prognostic 
tool, especially in case of mature and hypermature cataracts. Although it was feasible to evaluate lenses of dogs with elastography, the method proved viable for evaluating the lens of dogs, characterizing the types of cataracts and demonstrating decreased stiffness of the diseased lenses.

Although from the elastographic method the structures that have aqueous content appeared as low quality, their shear wave velocities (SWVs) were overestimated even when they did not represent the real value of rigidity, indicated by high sensitivity and specificity for the presence of cataract and at the incipient stage.

Acknowledgements.- The authors would like thank for: The authors would like to thank the "Fundação de Amparo à Pesquisa do Estado de São Paulo" (FAPESP, protocol numbers: 2012/6635-2 and 2013/23778-7) and "Conselho Nacional de Desenvolvimento Científico e Tecnológico" by research grant and productivity scholarship award (CNPq, processes 140189/2017-3 and 309199/2017-4). The authors also thank Jair Matos and Siemens Healthineers for technical assistance.

Conflict of interest statement.- The authors declare that they have no competing interest.

\section{REFERENCES}

Abreu T.G.M., Feliciano M.A.R., Renzo R., Kobashigawa K.K., Chacaltana F.D.Y.C., Crivelaro R.M., Silveira C.P.B., Cruz N.R.N., Aldrovani M., Maronezi M.C., Silva P.A., Thiesen R. \& Laus J.L. 2018. Acoustic radiation force impulse elastography of the eyes of brachycephalic dogs. Arq. Bras. Med. Vet. Zootec. 70(4):1045-1052.<https://dx.doi.org/10.1590/1678-4162-9498>

Adkins E.A. \& Hendrix D.V. 2005. Outcomes of dogs presented for cataract evaluation: a retrospective study. J. Am. Anim. Hosp. Assoc. 41(4):235-240. <https://dx.doi.org/10.5326/0410235><PMid:15995160>

Antunes A., Safatle A.M., Barros P.S. \& Morelhão S.L. 2006. X-ray imaging in advanced studies of ophthalmic diseases. Med. Phys. 33(7):2338-2343. <https://dx.doi.org/10.1118/1.2207135> <PMid:16898435>

Assia E.I., Rosner M. \& Medan I. 1997. Correlation between clinical, physical and histopathological characteristics of the cataractous lens. Graefes Arch. Clin. Exp. Ophthalmol. 235(12):745-748. <https://dx.doi.org/10.1007/ BF02332857><PMid:9439965>

Carvalho C.F., Cintra T.C.F. \& Chammas M.C. 2015. Elastography principle and considerations for clinical research in veterinary medicine cibele. J. Vet. Med. Anim. Health 7(3):99-110. <https://dx.doi.org/10.5897/JVMAH2014.0344>

Czygan G. \& Hartung C. 1997. On the correlation of mechanical and optical properties of cataractous eye lens nuclei. Biomedizinische Technik 42(1/2):26. <https://dx.doi.org/10.1515/bmte.1997.42.1-2.2><PMid:9086624>

Dick H.B., Allyeva S.E. \& Hengerer F. 2008. Effect of trypan blue on the elasticity of the human anterior lens capsule. J. Cataract Refract Surg. 34(8):13671373. <https://dx.doi.org/10.1016/j.jcrs.2008.03.041><PMid:18655989>

Galego M.P., Safatle A.M.V., Otsuki D., Hvenegaard A.P., Castanheira V.R. \& Barros P.S.M. 2012. Comparison of anterior ocular segment structures in healthy dogs, with diabetic or no diabetic cataract, by ultrasound biomicroscopy. Pesq. Vet. Bras. 32(1):66-71. <https://dx.doi.org/10.1590/ S0100-736X2012000100011>

Gelatt K.N. \& Wilkie D.A. 2011. Surgical procedures of the lens and cataract, p.305-352. In: Gelatt K.N. \& Gelatt J.P. (Eds), Veterinary Ophthalmic Surgery. Saunders Elsevier, Oxford.

Huang C.C., Ameri H., Deboer C., Rowley A.P., Xu X., Sun L., Wang S.H., Humayun M.S. \& Shung K.K. 2007. Evaluation of lens hardness in cataract surgery using high frequency ultrasonic parameters in vitro. Ultrasound Med. Biol. 33(10):1609-1616.<https://dx.doi.org/10.1016/j.ultrasmedbio.2007.05.002> $<$ PMid:17618041>
Huang C.-C., Chen R., Tsui P.-H., Zhou Q., Humayun M.S. \& Shung K.K. 2009 Mensurements of attenuation coefficient for evaluating the hardness of a cataract lens by a hight frequency ultrasonic needle transducer. Phys. Med. Biol. 54(19):5981-5994.<https://dx.doi.org/10.1088/00319155/54/19/021><PMid:19759408>

Kleiner J.A. 2007. Implante de lente intra-ocular acrílica dobrável de 41d em cães após facoemulsificação. Acta Scient. Vet. 35(Supl.2):s623-s625.

Kurapkienè A., Raitelaitienė R., Paunksnis A., Lukoševičius A., Burnovas S., Paunksnienė M., Svaldenienè E. \& Babrauskienè V. 2005. The relationship of ultrasonic and mechanical properties of human nuclear cataract. A pilot study. Ultragarsas 1(54):39-43.

Kuszak J.R., Zoltoski R.K. \& Sivertson C. 2004a. Fibre cell organization in crystalline lenses. Exp. Eye Res. 78(3):673-687. <https://dx.doi. org/10.1016/j.exer.2003.09.016> <PMid:15106947>

Kuszak J.R., Zoltoski R.K. \& Tiedemann C.E. 2004b. Development of lens suture. Int. J. Develop. Biol. 48(8/9):889-902.<https://dx.doi.org/10.1387/ ijdb.041880jk ><PMid:15558480>

Martins B.C., Rodrigues Jr E.F., Souza A.L.G., Almeida D.E., Brito F.L.C., Canola J.C., Brooks D. \& Laus D.B.J.L. 2010. A and B mode ultrasonography in preoperative evaluation of lens and posterior segment of dogs eyes with cataract. Pesq. Vet. Bras. 30(2):121-126. <https://dx.doi.org/10.1590/ S0100-736X2010000200004>

Mould J.R.B. 2002. Ophthalmic examination - protocol for ophthalmic examination, p.4-6. In: Jones P.S. \& Crispin M.S. (Eds), Bsava Manual of Small Animal Ophthalmology. British Small Animal Veterinary Association, England.

Ofri R.L. 2013. Lens, p.272-290. In: Maggs D.J., Miller P.E. \& Ofri R.L. (Eds), Slatter's Fundamentals of Veterinary Ophthalmology. Elsevier, Missouri.

Paszek M.J., Zahir N., Johnson K.R., Lakins J.N., Rozenberg G.I., Gefen A., Reinhart-King C.A., Margulies S.S., Dembo M., Boettiger D., Hammer D.A. \& Weaver V.M. 2005. Tensional homeostasis and the malignant phenotype. Cancer Cell 8(3):241-254.<https://dx.doi.org/10.1016/j.ccr.2005.08.010> <PMid:16169468>

Pigatto J.A.T., Pereira F.Q., Almeida A.C.V.R., Menezes C.L.M., Albuquerque L. \& Franzen A.A. 2007. Avanços e benefícios da facoemulsificação. Acta Scient. Vet. 35(Supl.2):s248-s249.

Rodrigues G.N., Ranzani J.J.T., Rodrigues A.C.L., Brandão C.V.S., Cremonini D.N., Clark R.M.O. \& Perri S.H.V. 2010. Facoemulsificação em cães, com e sem implante de lente intra-ocular em piggyback: estudo clínico da inflamação pós-operatória. Pesq. Vet. Bras. 30(2):103-107. <https://dx.doi. org/10.1590/S0100-736X2010000200001>

Safatle A., Hvenegaard A.P., Gomes D., Leandro D.C., Otsuki D. \& Lisak R. 2010 Importância do eletrorretinograma de campo total (Full field ERG) em cães da raça Cocker Spaniel Inglês portadores de catarata. Pesq. Vet. Bras. 30(2):149-154.<https://dx.doi.org/10.1590/S0100-736X2010000200009>

Shah S., Laiquzzaman M., Bhojwani R., Mantry S. \& Cunliffe I. 2007. Assessment of the biomechanical properties of the cornea with the ocular response analyzer in normal and keratoconic eyes. Invest. Ophthalmol. Vis. Sci. 48(7):3026-3031. <https://dx.doi.org/10.1167/iovs.04-0694> $<$ PMid:17591868>

Smith J.M., El-Brawany M., Nassiri D., Tabandeh H. \& Thompson G.M. 2002. The relationship between nuclear colour and opalescence on the LOCSIII scale and physical characteristics of cataract nuclei. Eye 16(5):543-551. <https://dx.doi.org/10.1038/sj.eye.6700119><PMid:12194066>

Tabandeh H., Wilkins M., Thompson G., Nassiri D. \& Karim A. 2000. Hardness and ultrasonic characteristics of the human crystalline lens. J. Cataract Refract. Surg. 26(6):838-841. <https://dx.doi.org/10.1016/S08863350(00)00305-9>

Temporini E.R. \& Kara-José N. 2004. Visual loss - prevention strategies. Arq. Bras. Oftalmol. 67(4):597-601. <https://dx.doi.org/10.1590/S000427492004000400007> 